\title{
The Early Monetary History of Roman Wales: Identity, Conquest and Acculturation on the Imperial Fringe
}

\author{
By PETER GUEST
}

\begin{abstract}
Over 52,000 Roman coins have been recorded and published from Wales. Using this comprehensive numismatic sample, this article investigates how coins of different metals and denominations were used and lost in western Britain during the later Iron Age and early Roman periods. The analysis of coins from hoards, excavated sites and single finds produces a more detailed picture of coin supply and use in Roman Britain than has been the case in the past and, consequently, it is now possible to provide a relatively sophisticated description of the monetization of Wales in the decades immediately before and after the conquest in the later first century A.D. The complexities of the early numismatic history of Wales are explored using a series of chronological and regional case-studies, while the discussion emphasizes the role of native traditions in shaping local responses to the appearance of coinage and the foreign practices associated with using Roman imperial currency.
\end{abstract}

\section{INTRODUCTION}

7 he mountainous western part of Britain included within the borders of modern Wales was only finally conquered by Rome some thirty-four years after the Claudian invasion of Britain in A.D. 43. For well over a generation, therefore, Wales lay outside the boundaries of the Roman Empire while the neighbouring tribes to the east were incorporated into the new and expanding province of Britannia. Thus, we have the perfect opportunity to study in detail how and under what circumstances Roman coins penetrated into the territory of the Welsh tribes before the conquest, and how the arrival of the Roman army in the Flavian period finally brought this region of Britain within the imperial coin-using economy. In this paper I shall look at the evidence for coin use in modern Wales from the later Iron Age to the end of the second century A.D., seeking to use the collected numismatic material to focus on the following questions:

- $\quad$ to what extent were coins used in Wales before the conquest?

- how did Roman coins arrive in Wales?

- what functions did Roman coins perform?

- $\quad$ can we detect different responses to Roman coinage? ${ }^{1}$

\footnotetext{
1 Versions of this article were given at the European Science Foundation's 'Roman Coins Outside the Empire' Exploratory Workshop hosted by Warsaw University in Nieborów, Poland in 2005, and the 'Regionality in Roman Britain' course organized by the University of Oxford's Department for Continuing Education in 2006. I am grateful to Aleksander Bursche, Hella Eckardt and to this journal's referees for their comments and suggestions.
} 


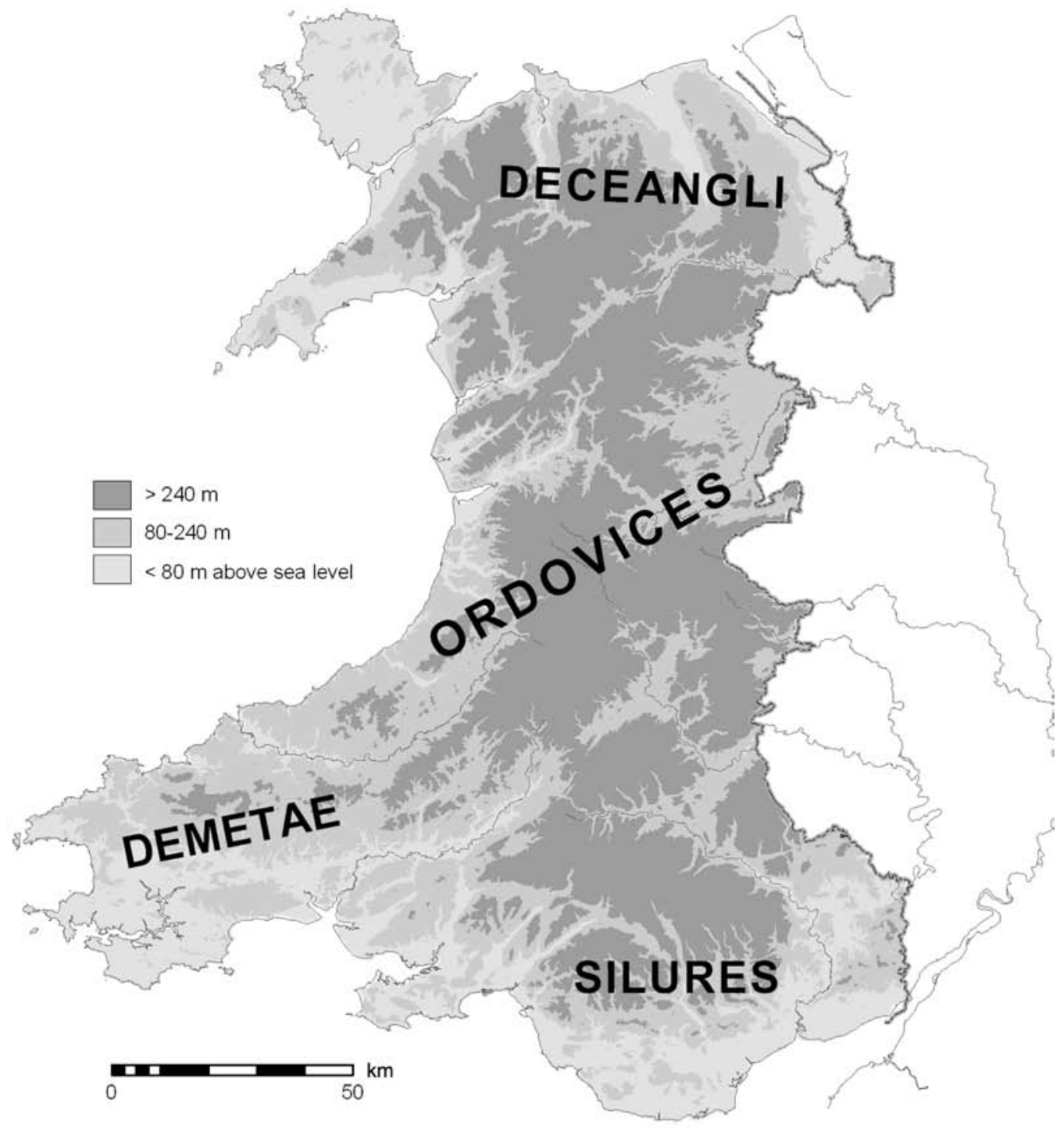

FIG. 1. Native tribes of Iron Age Wales.

\section{HISTORICAL BACKGROUND}

By A.D. 47 a large part of the lowland area of southern Britain was firmly under Roman control. The first governor, Aulus Plautius, had defeated the tribes who opposed the invasion in A.D. 43 and had quickly received the surrender of several others. In a short time the Roman army was pushed out to the west and north to protect the new province and confront those who continued to oppose the Roman presence in Britain. We are told that the leader of the native resistance was 
Caratacus, 'king' of the Catuvellauni, who fled westwards after his defeat in A.D. 43 to seek refuge with the unconquered tribes of Wales. The literary and epigraphic sources indicate that Wales and the Marches lay within the territories of at least four tribes: the Silures, Demetae, Ordovices, and Deceangli (FIG. 1). In A.D. 47 Plautius was replaced by Ostorius Scapula who led the army against these tribes in a series of campaigns that culminated in a victory against the Britons in A.D. 51. Once again Caratacus was forced to flee, this time to the Brigantes in northern England, although Roman control of Wales was far from complete and the Silures in particular continued to resist. From A.D. 51 it appears that the Roman army was able to wear down the Welsh tribes, albeit gradually, and in A.D. 60 the governor Suetonius Paullinus launched an attack on the last native stronghold on Anglesey. The rebellion in eastern England of the Icenian queen Boudicca, however, would delay the final conquest of Wales for over a decade. The Boudiccan revolt and its aftermath forced a change of Roman policy in Britain and it was only in A.D. 73/4 that the army under Julius Frontinus was in a position to recommence the war with the Welsh tribes. In the end the final conquest was achieved with remarkable speed and by the end of A.D. 77 Wales had been completely subjugated. ${ }^{2}$

For the next forty years or so after the Flavian conquest Wales was occupied by a substantial garrison of the Roman army in Britain (FIG. 2). An extensive network of auxiliary forts designed to control the populations and their movements was established across Wales - a system of domination and suppression that spread out from the two legionary fortresses at Caerleon and Chester. From the reign of Hadrian the garrison in Wales was steadily reduced as the North became the focus of military activity in Britain and, while the bases of Legion II Augusta and Legion XX Valeria Victix on the southern and northern approaches into and out of Wales continued in use, perhaps only five auxiliary forts in Wales were occupied after $c$. A.D. 160. The earliest withdrawal of troops coincided with the foundation of the civitas capitals at Caerwent and Carmarthen (Venta Silurum and Moridunum respectively), and the appearance for the first time of Romanized rural farmsteads (villas) in the south of the country. During the course of the second century the two towns grew and developed, while Roman material culture and building traditions became more common in the countryside, particularly in coastal areas. It is also the case, however, that the populations in large parts of Wales never adopted the customs or habits of a Roman way-of-life and so, archaeologically-speaking, remained largely prehistoric. ${ }^{3}$

\section{NUMISMATIC BACKGROUND}

Wales has an unsurpassed record for the reporting of ancient coin finds. In 1923 Wheeler published the first systematic inventory of coin hoards from Wales, while Nash-Williams' 1928 survey of Roman monuments in south Wales included descriptions of hoards as well as other coin finds. ${ }^{4}$ Hoards continued to be the main source of evidence and a great deal of new material was published in George Boon's lists in the 1960s and 1970s. ${ }^{5}$ Boon also identified many assemblages of archaeologically-recovered coins, publishing them in excavation reports and journal articles (a relatively recent innovation at the time). ${ }^{6}$ The first general survey of all Roman coins from Wales, including archaeological site-finds, appeared in 1983 in which Jeffrey Davies brought together the material published by Wheeler, Nash-Williams, Boon and others, and used it to create one of the first regional numismatic narratives for Roman Britain. ${ }^{7}$ The twenty years since

\footnotetext{
For recent summaries see Arnold and Davies 2000, 3-15; Jarrett 2002; Manning 2002.

Arnold and Davies 2000, 15-26 and 45-51.

Wheeler 1923a; 1923b; Nash-Williams 1928.

Boon 1967; 1975; 1978.

For example, Boon 1964 and 1965.

Davies 1983.
} 

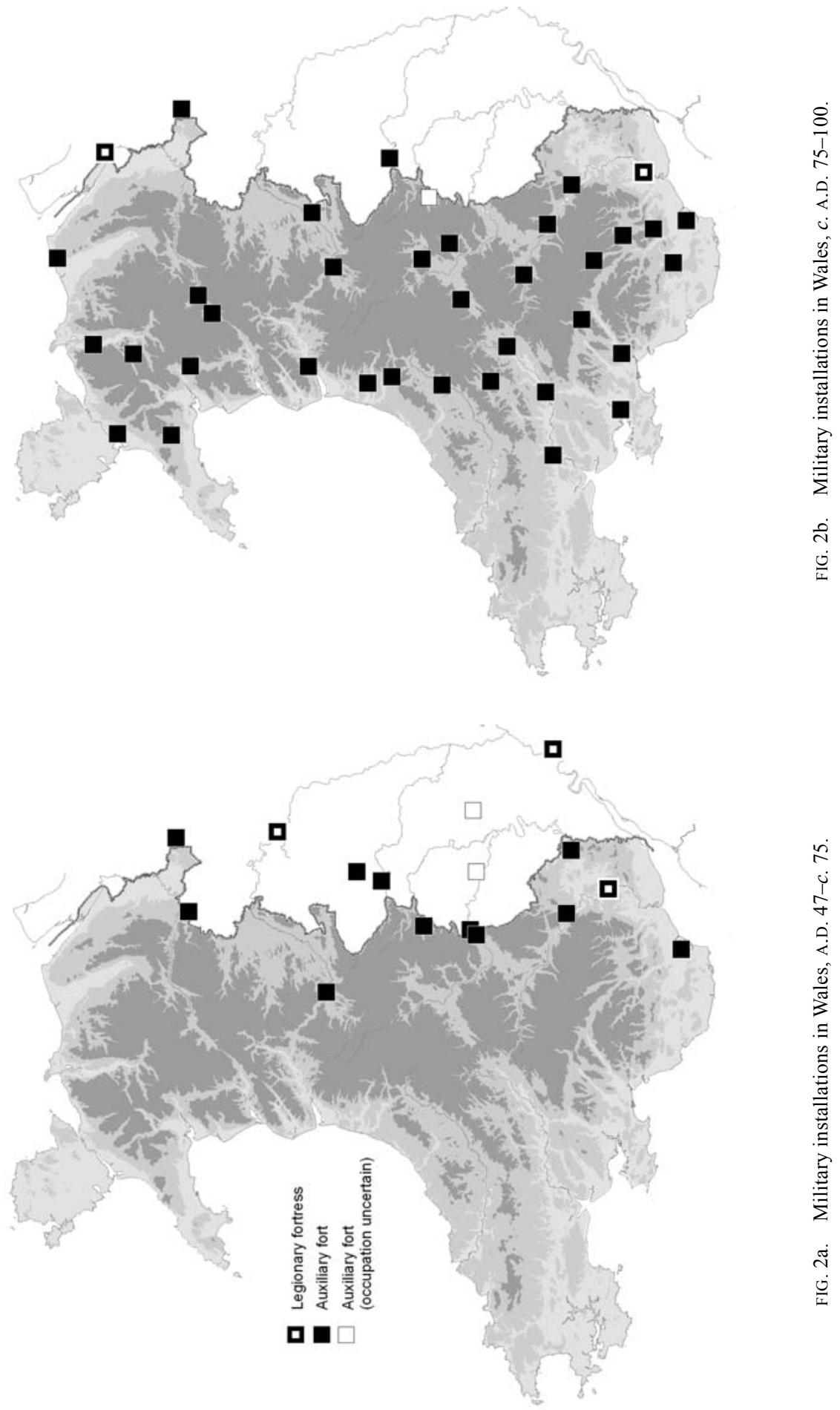

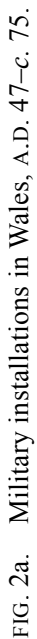



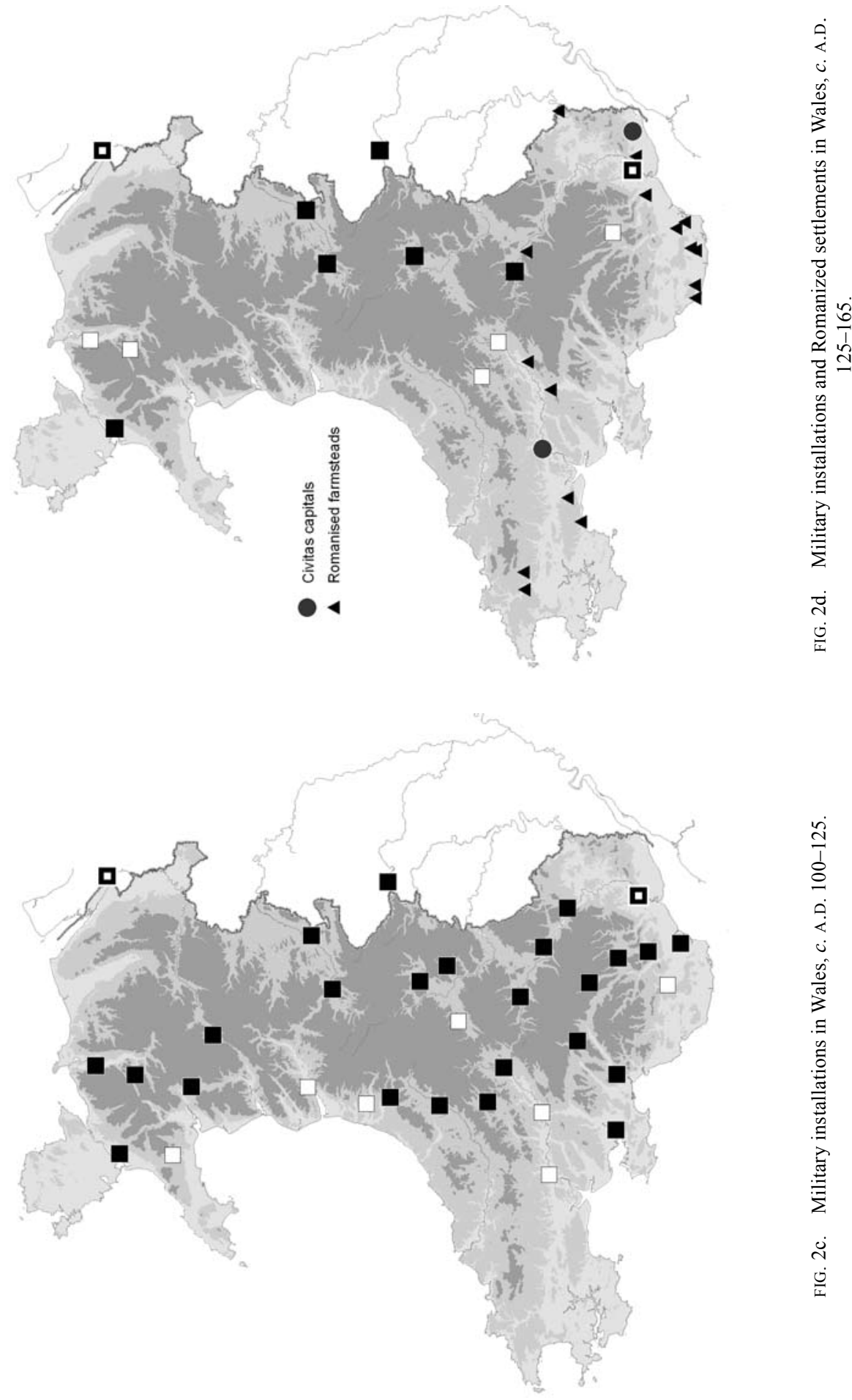

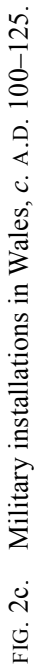


1983 have seen enormous growth in the quantity of Roman coins found in Wales, particularly since the metal detector became widely available. The relatively benign British treasure law introduced in 1997 was accompanied by the establishment of the Portable Antiquities Scheme and today many thousands of coins discovered by metal-detectorists are known that otherwise would have been lost to us. Also, excavated assemblages of coins are a more familiar category of find now than two decades ago and many groups of site-finds have been recovered during fieldwork in Wales (Edward Besly, at the National Museum Wales, continues the Welsh tradition of prompt and detailed reporting of coin finds of all types). Often this material is published, although in certain instances the only descriptions of coin finds are located in the regional Sites and Monuments Records. Despite the increase in material being discovered, no attempt has been made recently to collate and reassess the Roman coinage in Wales.

In 2003, however, Cardiff University initiated a project to do just that and Iron Age \& Roman Coins from Wales (IARCW) recorded and published details of over 52,000 coins from 1,172 separate finds (including hoards, excavated assemblages, survey and single finds, or 'groups' whose contents or circumstances of deposition are uncertain). ${ }^{8}$ The theory of 'applied numismatics' proposes that there is a direct link between the supply of coinage to places such as Wales and the loss of coins in archaeological contexts. This is based on the principle that only those coins available to be used can have been lost, discarded, or deliberately deposited in a particular location, though the relationship between supply/use and loss/recovery inevitably is complicated by various cultural and taphonomic factors. Nevertheless, as long as any analysis of archaeologically-recovered coinage is aware of, and sensitive to, the effects of these complications, in principle it should be possible to use this comprehensive sample of coin loss from across Wales to provide an accurate and reliable picture of coin supply and use in this part of Western Britain during the Roman period. ${ }^{9}$

The numismatic data from Wales can be analysed in various ways, though the method of analysis will depend on the questions asked. Looking at where Roman coins are found, for example the distributions of different emperors' issues and their metals, can be a rewarding approach and in this case it is used to produce a better understanding of the coinage supplied to Wales and how coins were used by the diverse population there. For the time being the distribution plots show only the presence of coins and in future the scale of individual finds will need to be taken into account as this may reflect the volume of coinage in circulation at different places. Nevertheless, this case-study will show how coinage becomes, by simply looking at where coins are found, another category of archaeological artefact that can be used to describe cultural as well as historical narratives.

It is important to consider the general background of coin finds in Wales before the patterns of early Roman coin finds are examined in detail. This is because we must be aware of, and appreciate, the overall picture in order to assess the significance of distributions for particular coins or coinages. For instance, if south-west Wales produces a concentration of coin finds of a particular period, is that because the territory of the Demetae always produces more coins than other areas, or is the concentration limited to coins of that period alone? Taking account of the numismatic background will result in interpretations of localised patterns that are more reliable and, consequently, more meaningful. ${ }^{10}$ FIG. 3 shows the distribution of all find-spots of Iron

8 Guest and Wells 2007. The complete IARCW database is available through the Archaeology Data Service / AHDS Archaeology website, currently located at: http://ads.ahds.ac.uk/catalogue/archive/iarcw_bcs_2007/(accessed 11 January 2007).

9 Casey 1986, 68-74; 1988; Kent 1988; Reece 1987, 114-26; 1996; 2002, 89-106. Recently, theories of applied numismatics have been applied to the collected coin finds from Britain and the Western provinces of the Roman Empire with significant results: for example, Hobley 1998; Walker 1988.

10 For instance, the concentration of archaeological excavation on certain site types, or surveys of particular areas, will affect the spatial distributions of coin finds. Only by taking such biases into account is it possible to achieve a genuine picture of a geographical area's numismatic history. 


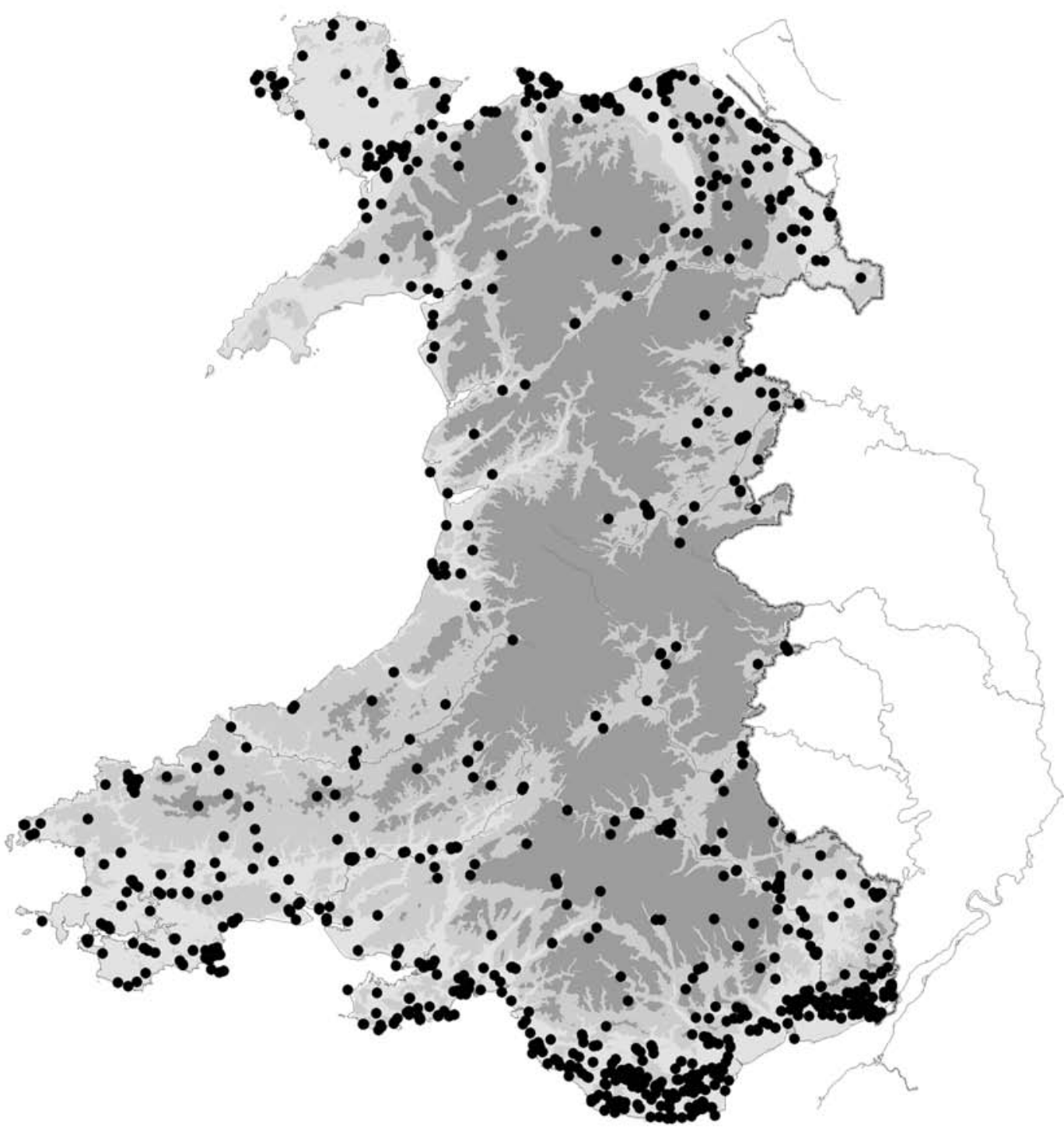

FIG. 3. Iron Age and Roman coins from Wales (1,172 find spots).

Age and Roman coins in Wales and it is immediately apparent that finds are concentrated in the coastal areas, particularly in the south and north, as well as along the river valleys that dissect the Welsh uplands. It is also important to draw attention to areas where coins have not been recorded, since the absence of material culture can be as significant as its presence. In Wales very few coins have been recovered from the highlands (defined as land above $240 \mathrm{~m}$ ) and some coastal regions, for example the Lleyn Peninsula on the north-western tip of mainland Wales. 


\section{DESCRIPTION}

IRON AGE COINS IN WALES

None of the tribes that inhabited the area of modern Wales produced their own coins and coinage was not part of the indigenous cultures before the Roman conquest. Therefore, all Iron Age coins that are found in Wales were imported from other, coin-producing, parts of Britain and the Continent. Only 35 Iron Age coins have been recovered from Wales (FIG. 4), which is a surprisingly small number, particularly when compared to the quantities found beyond the River Severn in Gloucestershire and northern Somerset. ${ }^{11}$ Yet, Iron Age coins are not found everywhere and their distribution shows a strong concentration in south-eastern Wales. Furthermore, the majority of Welsh Iron Age finds are of gold coins, all of which were found as single finds (with the possible exception of the three gold coins from 'Glamorganshire' that could be a hoard, see Table 1).

Almost half of the Iron Age coins from Wales were struck by the Dobunni ('Western' issues), a tribe whose territory stretched eastwards from the River Severn (Table 2). Coins of the tribes of southern and eastern England are relatively rare from Wales, as are Continental issues (Welsh finds

TABLE 1. IRON AGE COINS FROM WALES: METALS AND CIRCUMSTANCES OF DISCOVERY

$\begin{array}{lccccc} & \text { Single finds } & \text { Hoard } & \text { Excavated coins** } & \text { 'Groups'*** } & \text { Total } \\ \text { Gold } & 17 & & & 3 & 20 \\ \text { Silver } & 3 & 3 * & 2 & 1 & 9 \\ \text { Copper alloy } & 1 & & & 1 & 2 \\ \text { Potin } & 2 & & 1 & & 3 \\ \text { Uncertain } & 1 & & & 5 & 1 \\ \text { Total } & 24 & 3 & 3 & \end{array}$

* Hoard of 3 silver coins from Minfford, Portmeirion, Gwynedd.

** Silver coins excavated from Caldicot and Whitton, and a potin from Caerwent.

*** 3 'Groups' of coins: 'Glamorganshire' (3 gold staters), Landovery (1 silver coin with 4 mixed Roman coins), and Llanfaes ( 1 bronze coin of the Carnutes found together with a Roman coin).

TABLE 2. ORIGINS OF IRON AGE COINS FROM WALES

$\begin{array}{lcccccc} & \text { Gold } & \text { Silver } & \text { Bronze } & \text { Potin } & \text { Uncertain } & \text { Total } \\ \text { Western } & 13 & 3 & & & & 16 \\ \text { South-western } & & 1 & 1 & & & 2 \\ \text { Southern } & 1 & 1 & & & & 2 \\ \text { Northern } & 1 & 1 & & & & 2 \\ \text { North-eastern } & 2 & & & & & 2 \\ \text { Potin } & & 1 & 1 & & 1 & 2 \\ \text { Continental } & 3 & 2 & & & 2 & 35 \\ \text { Uncertain } & 20 & 9 & 2 & 2 & & \\ \text { Total } & & & & & & \end{array}$




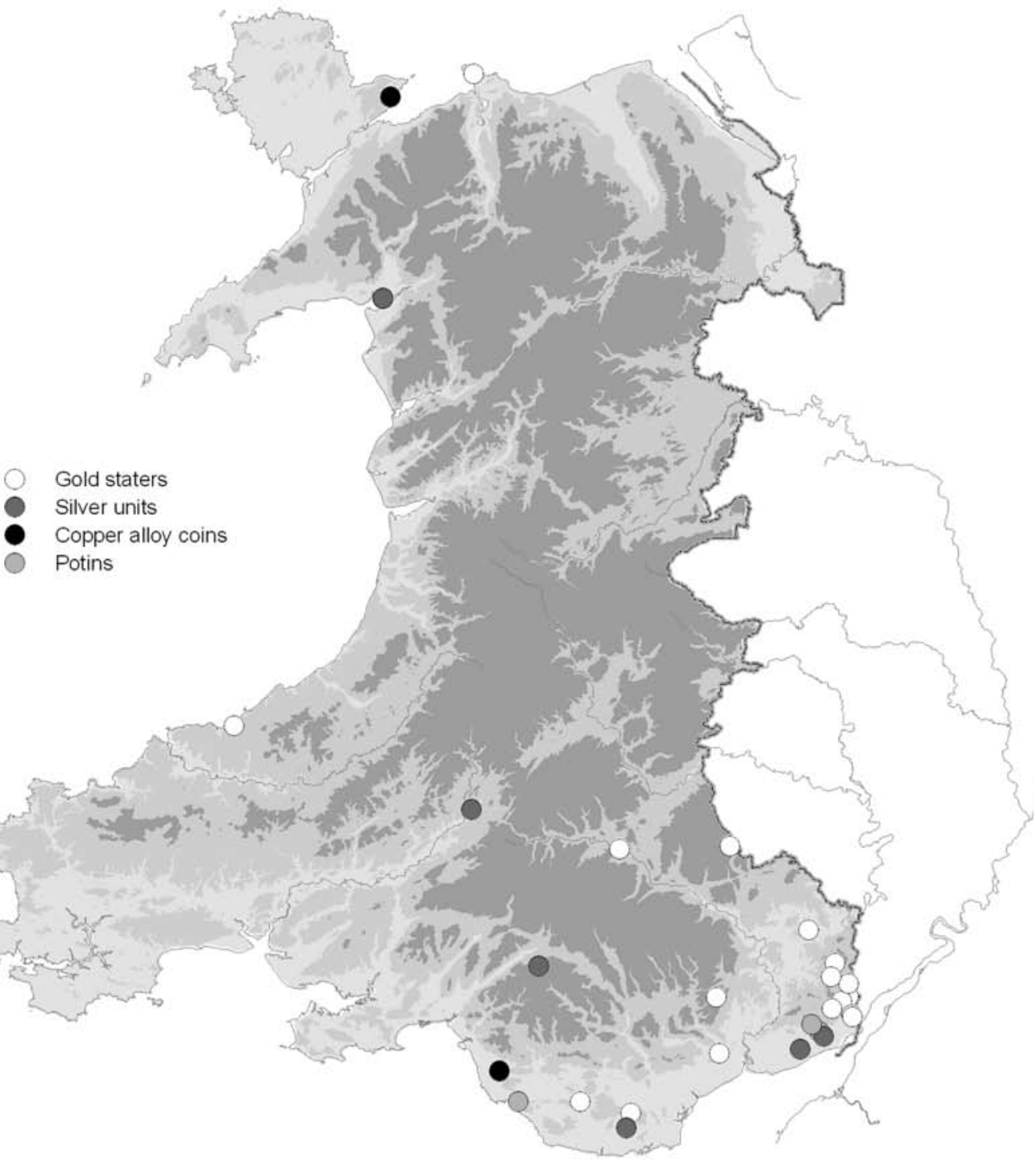

FIG. 4. Iron Age coins from Wales.

include single coins of the Turones, Carnutes, and Aedui). The absence of coins from the Hertfordshire/Essex area is puzzling given how Roman authors describe events in the years after the invasion of Britain in A.D. 43. Tacitus tells how Caratacus fled to Wales where he continued to lead the resistance against Roman attempts to subdue the local tribes until his final defeat and capture in A.D. $51 .{ }^{12}$ However, the eight-year presence of Caratacus and his followers, who came from 


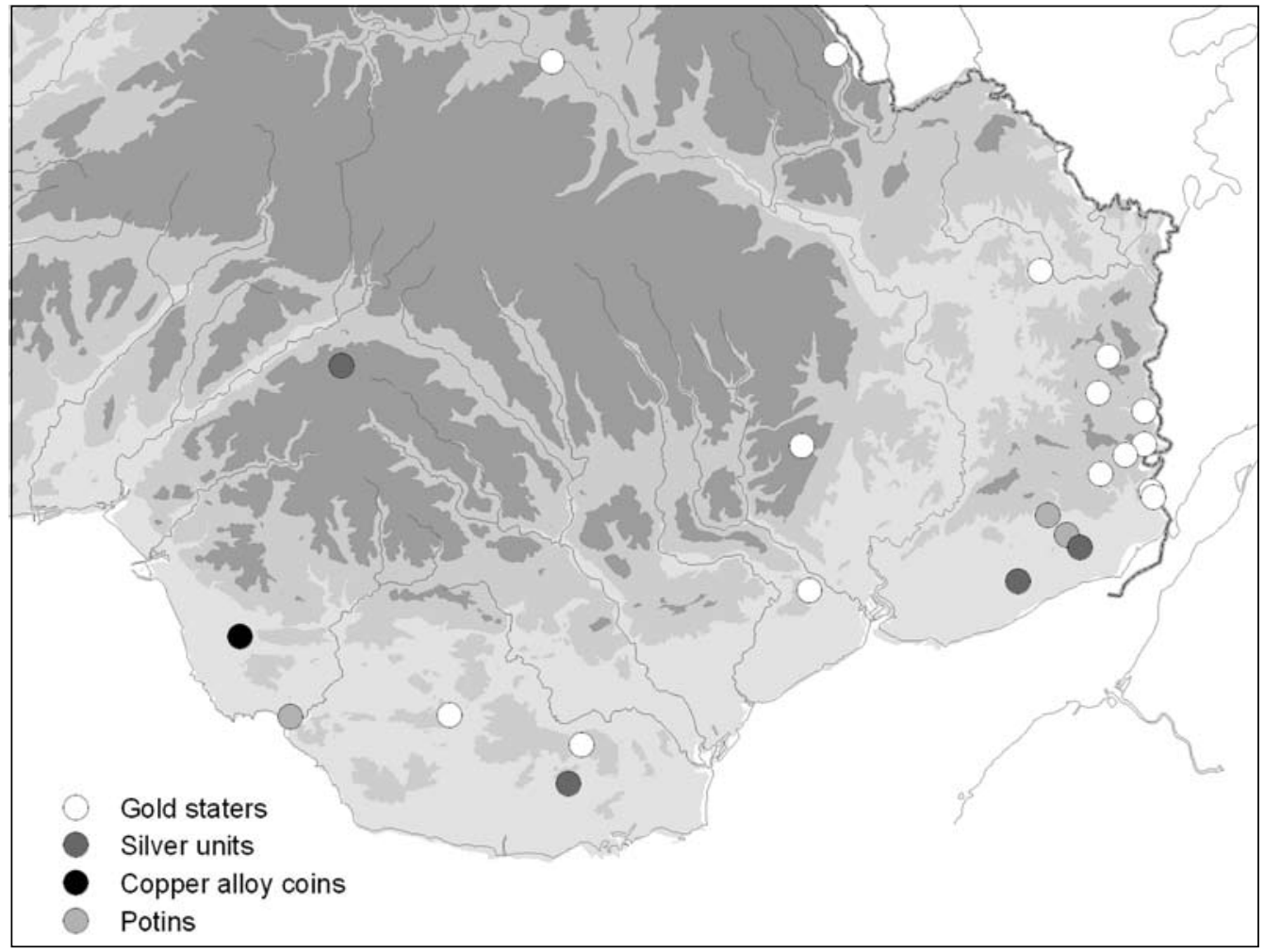

FIG. 5. Iron Age coins from south-east Wales.

coin-producing tribes, has left no discernible trace in the archaeological record, even in the general area of Ordovician territory in central and western Wales. It appears that if Caratacus brought any quantity of coins with him on his flight to the Welsh tribes they did not end up in the ground.

A noticeable feature of the distribution of Iron Age coins in south-east Wales is the concentration, largely of gold coins, between the Rivers Usk and Wye (FIG. 5). The native tribe in this area were known to the Romans as the Silures and there has been some debate about where the boundary between the Silures and the Dobunni to the east actually lay. While the pattern of Iron Age coin finds in this area is superficially similar to the situation in Gloucestershire, the absence of silver issues from Wales is noteworthy and the overall pattern should not be taken as evidence that Dobunnic influence extended beyond the Wye. The river, or more precisely the hills above its west bank, apparently formed a barrier, or filter, to the spread of Iron Age coins into Wales, except for a small number of high-value issues. The effectiveness of the river as a culturally constructed obstacle becomes clearer when we consider that many of the Iron Age coins found to the west of the Wye were found in association with Roman coins, or on settlements only established in the Roman period, and must, therefore, have been lost some time after the conquest in the later first century. ${ }^{13}$ This impermeability of the Wye and the Welsh highlands suggests a political or 
cultural rejection of coinage and very different exchange systems on either side of the coin-using / non-coin-using boundary in the later Iron Age.

\section{CLAUDIAN COINS}

The distribution of Roman coins struck in the name of Claudius (A.D. 41-54) reveals how quickly coinage penetrated into Wales after the conquest (FIG. 6). It is most likely that these coins were brought by the army as it expanded Roman control westwards during the campaigns of the Flavian period. Claudian coins are frequently found on military sites in south Wales first occupied after A.D. 73/4-77, which shows that they remained in circulation for at least fifteen years after they were struck and possibly much longer (though Claudian coins are less common in second-century hoards). Claudian copies, local imitations of official bronze coins, are closely associated with the archaeology of the Roman army in Britain and it is thought that these copies were semi-official coins, authorized and issued by the military during the years up to A.D. 64 when the Roman mints once again began satisfying provincial demand for low-value bronze denominations. ${ }^{14}$ The difference between the demand for and supply of bronze coins was such that 218 of the 261 Claudian bronze coins from Wales (84 per cent) are copies, though it is noteworthy that official coins have a wider distribution than the more numerous copies. Claudian coins occur more often in south Wales, particularly along the Usk valley from the legionary bases at Usk and Caerleon to the fort at Brecon. Other finds along the south coast show the influence of the Roman army as it spread westwards from Caerleon after A.D. 75. The paucity of any Claudian coins from central and north Wales suggests a different numismatic history of the conquest in these regions that were brought under Roman control from Wroxeter and Chester.

\section{FLAVIAN COINS}

Coins of the Flavian emperors (Vespasian, Titus and Domitian) are found more widely across Wales and their distributions reflect the militarization of the landscape after A.D. 77 (FIGS 7 and 8). Coins of all metals - especially silver and bronze - are recovered from most parts of Wales and there is no difference in the spatial distributions of high- and low-value coinage of this period. On the other hand, late first-century Roman coins barely penetrated the highest parts of central Wales other than along river valleys, and even there Roman coins do not seem to have been used beyond the limits of the forts and their vici. The picture is, of course, complicated by the fact that Flavian coins were not lost only during the first century and we know that these issues remained in circulation for decades after they were struck (particularly the bronze denominations). Nonetheless, it is clear that Roman coinage was brought to Wales by the army and that this westernmost part of Britain was effectively 'monetized' within a relatively short space of time (perhaps only one or two generations after the conquest), although some areas took to using coins more readily than others. ${ }^{15}$

14 Boon 1982, 11; Walker 1988, 285. Evidence from Colchester indicates that Claudian copies were being prepared and struck in the legionary fortress there. Brass-making crucibles found during the excavations at Culver Street may well have been for the production of orichalcum dupondii, while numerous die-links between copies make it clear that the fortress was a major minting centre (Kenyon 1987, 33-4). George Boon's survey of the coins from the fortress at Usk showed that Claudian copies were still in production after A.D. 55 (Boon 1982, 11) and most numismatists would now agree that these coins continued to be struck until c. A.D. 64, when Nero reopened the mint at Lugdunum and the systematic striking of official bronze coinage began again.

15 'Monetized' is often used by numismatists to describe an economy in which coins fulfilled a monetary function in commercial transactions. Here, however, I use the term to mean that Wales became part of the coin-using Roman world, without necessarily implying that coins were used as money. In the absence of a more suitable term to express the process by which coin-use spreads through a society, I shall continue to use monetized to mean coin-using. 


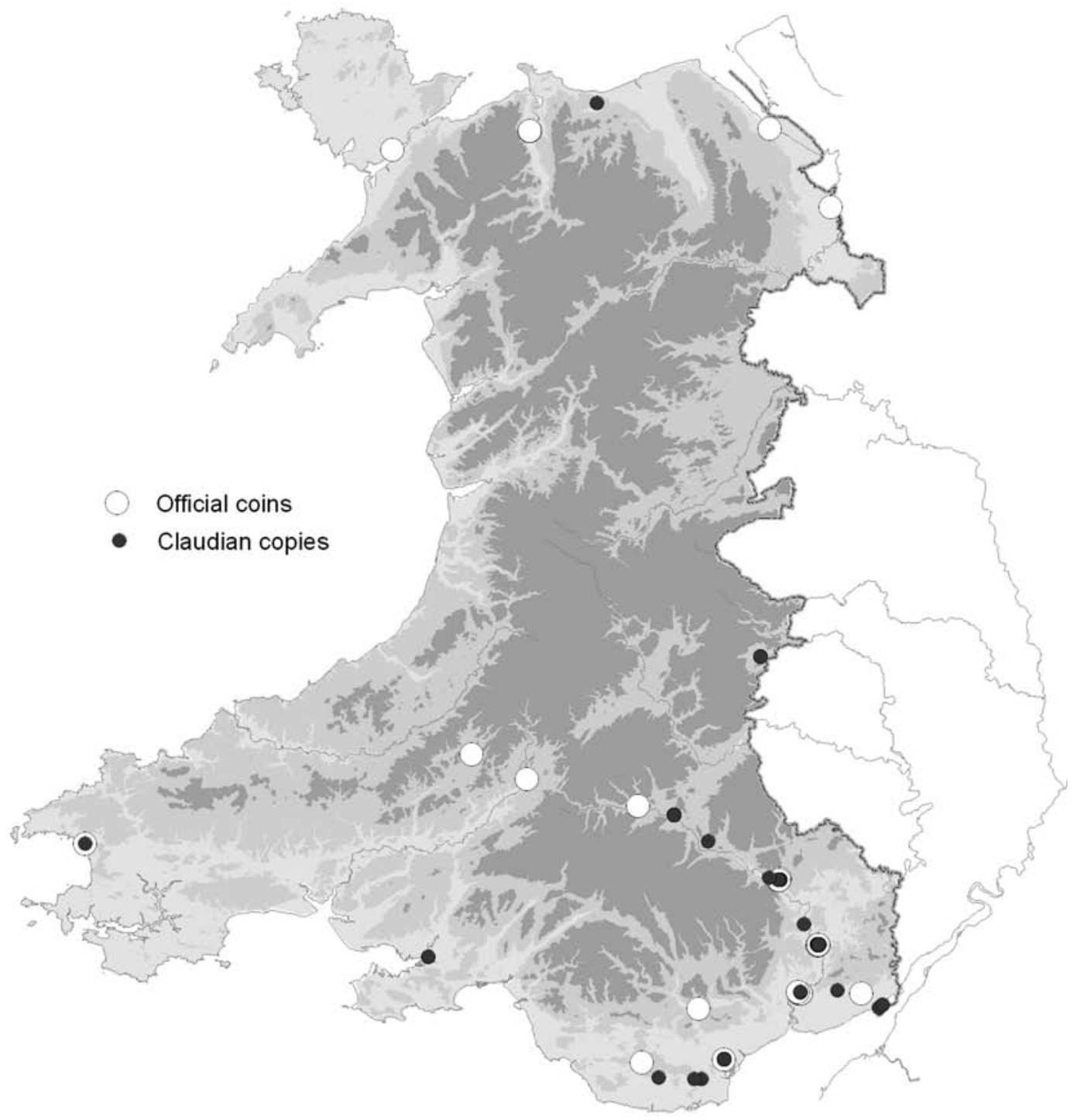

FIG. 6. Claudian coins from Wales.

\section{NERVA TO COMMODUS}

The distribution of second-century coins (A.D. 96-192) shows a very similar pattern to Flavian coinage (FIG. 9). During these years the military forces in Wales were reduced and the towns at Caerwent and Carmarthen were established, while a number of Romanized rural farmsteads (villas) appeared in the south of the country. The monetization of Wales, however, survived the departure of the army, even in areas where other forms of Roman culture are otherwise lacking, 


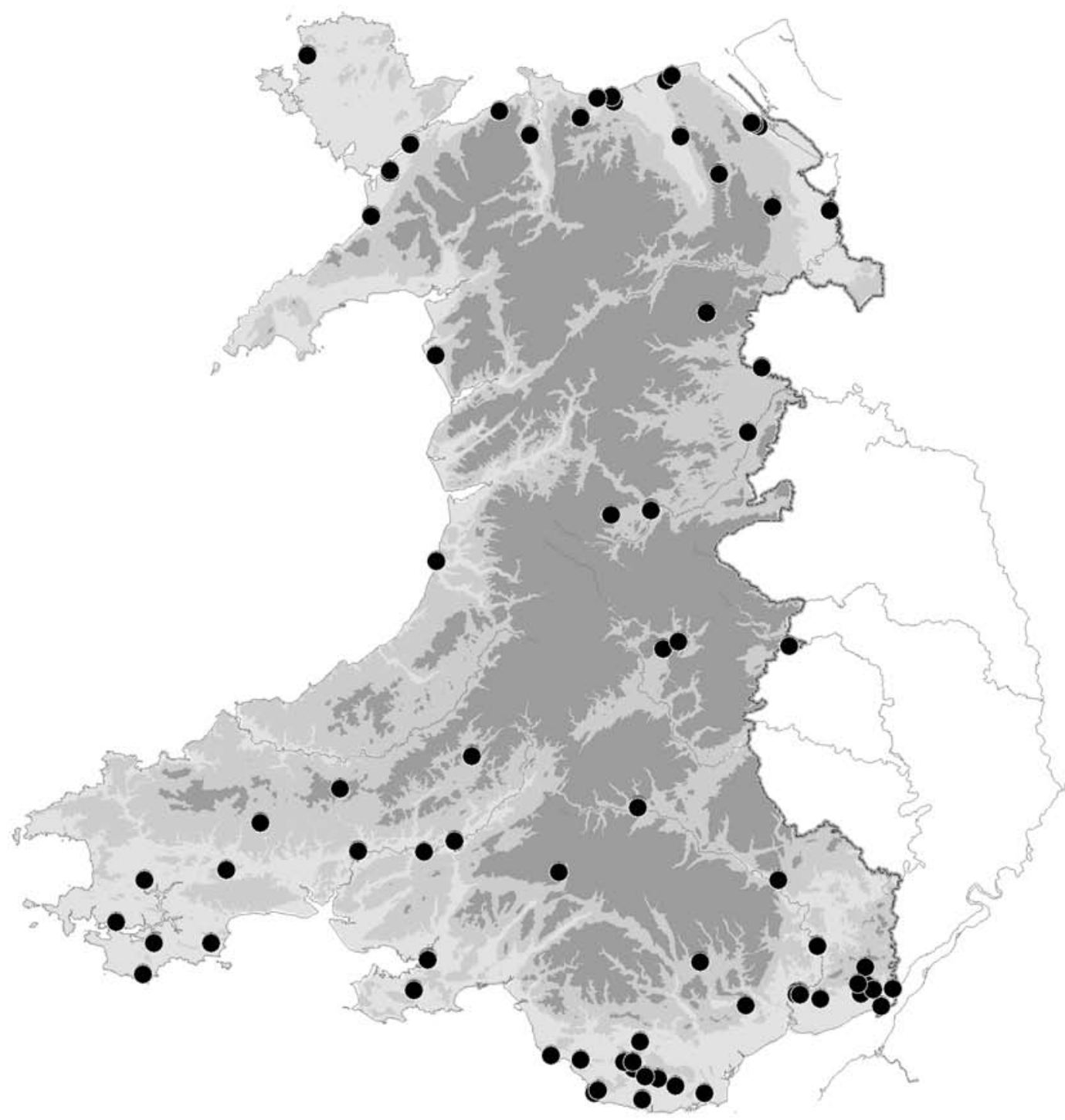

FIG. 7. Flavian denarii from Wales.

and coins were to remain a characteristic feature of Roman Wales. Many rural sites on the north and south coasts produce coins of the first and second centuries, often in large quantities, and many hoards are known from these areas too. It is also the case, however, that hardly any coins have been recovered from large parts of Wales. The absence of early Roman coins from the highlands may be related to the nature of the economy and the local populations, which either did not require coins or only saw their use in specific locations (for example, seasonal 


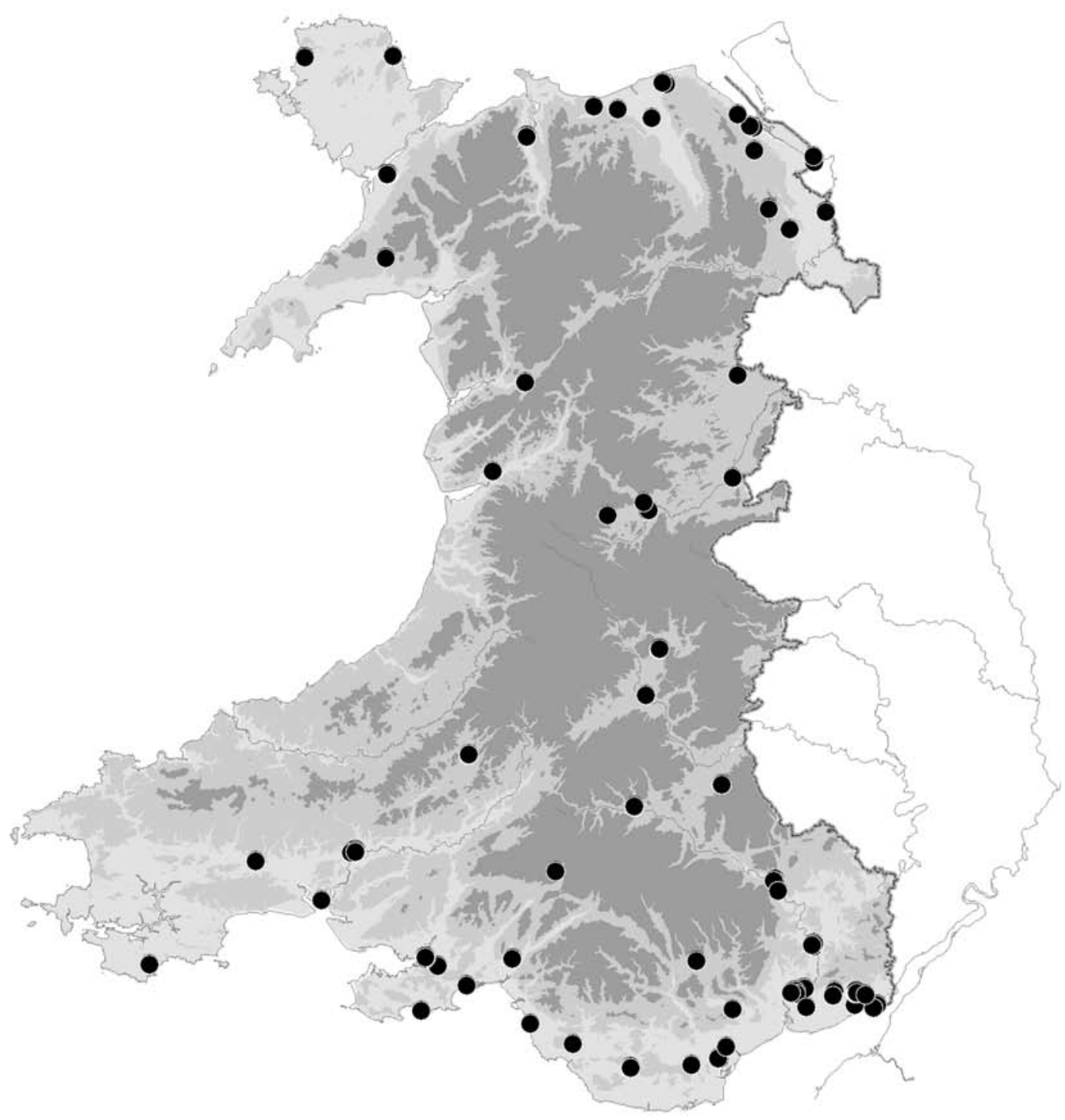

FIG. 8. Flavian bronze denominations from Wales.

markets). Alternatively, this pattern might also occur if the ability to use coins was deliberately withheld from these regions, or if coins were actively resisted by their populations. The absence of early Roman coin finds outside military contexts from large areas such as coastal west Wales or Gwynedd, including the Lleyn Peninsula, cannot be explained as modern phenomena, but is most likely to be a reflection of the ancient pattern of coin supply and use. The archaeological evidence shows that these landscapes contained numerous unenclosed and enclosed rural 


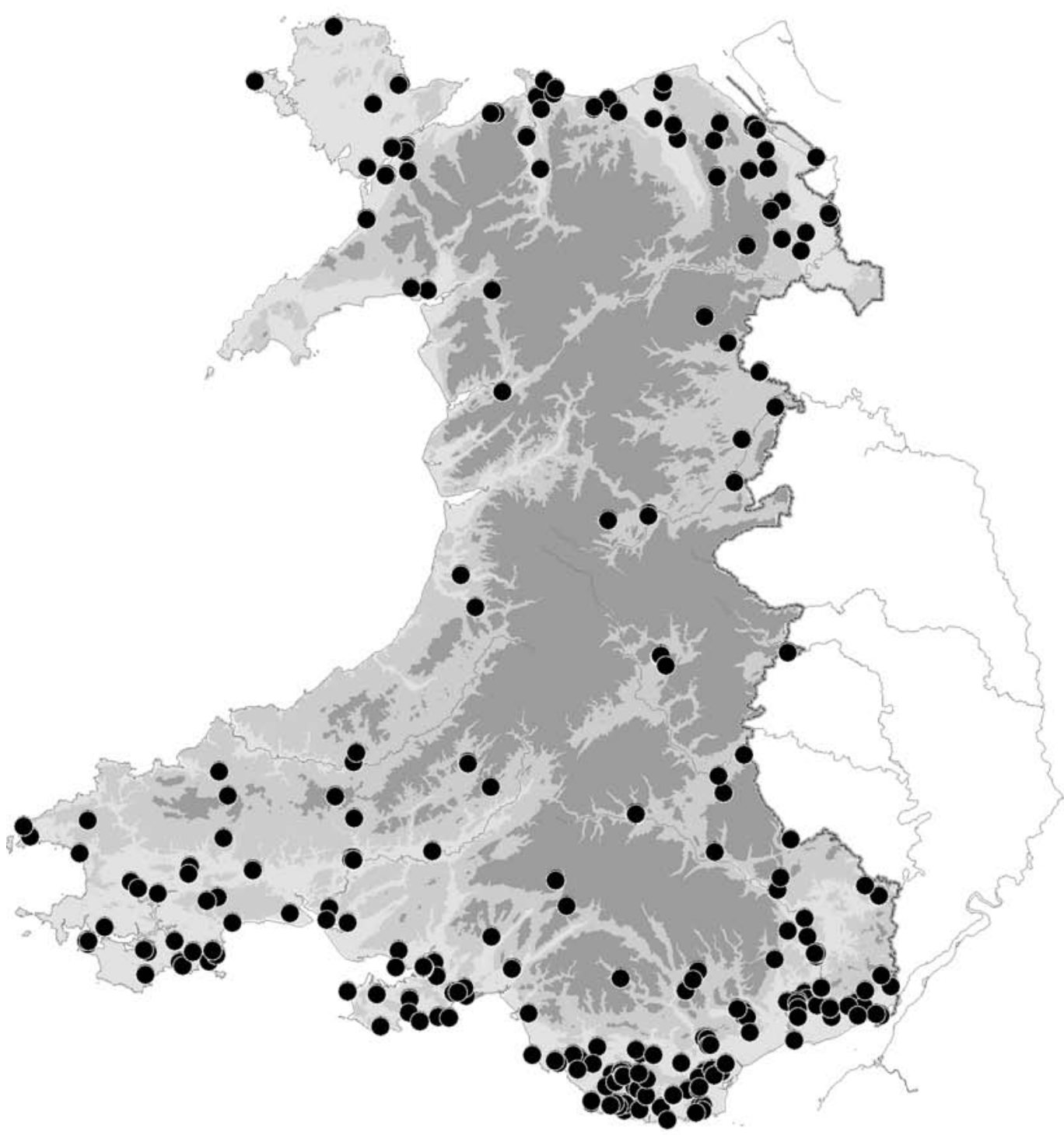

FIG. 9. Second-century coins (A.D. 96 to 192) from Wales.

settlements, though the paucity of Roman material culture (including coins) from the few sites that have been systematically excavated is certainly noteworthy. ${ }^{16}$ Is it possible that the nature

16 See note 3, and Kelly 1990 and Davies 1984 for summaries. Several so-called 'hut group' settlements of various morphological types have been excavated in Gwynedd and Anglesey in recent years, most notably at Bush Farm and Bryn Eryr, Anglesey (Longley et al. 1998), as well as in the Graeanog area south-west of Carnarvon (Fasham et al. 1998). None has produced coins. 
of the economies practised by the local populations did not require the use of coins in any great quantities, or that the inhabitants of these areas were somehow able to reject their use?

\section{COIN SUPPLY AND USE}

The military's role in the early monetary history of Roman Wales can be seen in the quantities of coins from sites and settlements recovered by excavation and surface surveys (Table 3 ). The legionary fortress at Caerleon and the numerous auxiliary forts have collectively produced twothirds of all Roman coins of the first and second centuries from Wales, and when the civilian settlements outside the gates of these installations are added the proportion rises to 82 per cent. To a large extent this reflects the fact that archaeologists have spent a disproportionate amount of time excavating fortresses, forts, and, more recently, their civilian suburbs, yet when these early Roman coins are examined in detail, it is clear that the situation is far more complex than this explanation suggests (Table 3 and FIG. 10). Specifically military sites account for 90 per cent of all Claudian coins from Wales, but this proportion falls steadily during the first and second centuries until the army produces only 36 per cent of Commodan coins (A.D. 180-192). Over the same period, the quantities of coins from the canabae and vici outside military installations increase from zero to 32 per cent (these civilian settlements produce very few pre-Flavian coins). Therefore, by the end of the second century almost as many coins are recovered from settlements outside forts as from the forts themselves.

TABLE 3. FIRST- AND SECOND-CENTURY COINS FROM EXCAVATED SITES IN WALES

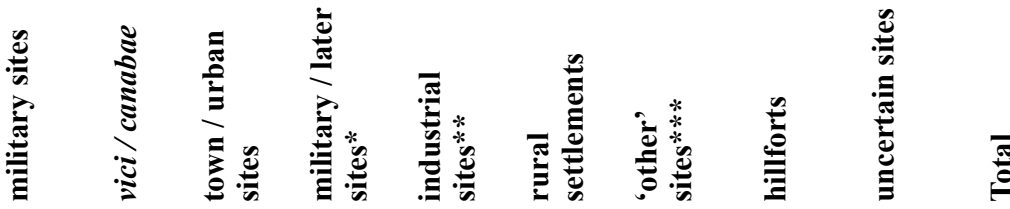

\begin{tabular}{|c|c|c|c|c|c|c|c|c|c|c|}
\hline to 41 & 111 & 16 & 5 & 3 & 1 & 2 & & 1 & & 139 \\
\hline $41-54$ & 187 & & 3 & 18 & & & & 1 & & 209 \\
\hline $54-68$ & 76 & 3 & 3 & 5 & & & 1 & & & 88 \\
\hline $69-96$ & 524 & 102 & 83 & 7 & 11 & 4 & 2 & 1 & 1 & 735 \\
\hline $96-117$ & 243 & 58 & 65 & 1 & 7 & 7 & 1 & 2 & 3 & 387 \\
\hline $117-38$ & 122 & 43 & 39 & 1 & 4 & 4 & 3 & & 1 & 217 \\
\hline $138-61$ & 100 & 68 & 46 & 2 & 4 & 3 & 1 & 2 & & 226 \\
\hline $161-80$ & 58 & 37 & 18 & & 1 & 3 & 1 & & & 118 \\
\hline $180-92$ & 16 & 14 & 13 & & & 1 & & & & 44 \\
\hline Total & 1437 & 341 & 275 & 37 & 28 & 24 & 9 & 7 & 5 & 2163 \\
\hline$\%$ & 66.4 & 15.8 & 12.7 & 1.7 & 1.3 & 1.1 & 0.4 & 0.3 & 0.2 & \\
\hline
\end{tabular}

* Includes excavations in Monmouth and Abergavenny where early forts (presumed in the case of Monmouth) were succeeded by non-military occupation.

** Includes sites at Lower Machen in south Wales and Flint, Ffrith and Prestatyn in north Wales.

*** Generally cave sites or coins from re-used prehistoric monuments.

Despite the different numismatic histories of various categories of settlement, all sites in Wales generally produce similar proportions of excavated silver and bronze coins. In the period up to A.D. 68 (FIG. 11) military and urban sites tend to generate relatively more bronze coins ( 80 per 


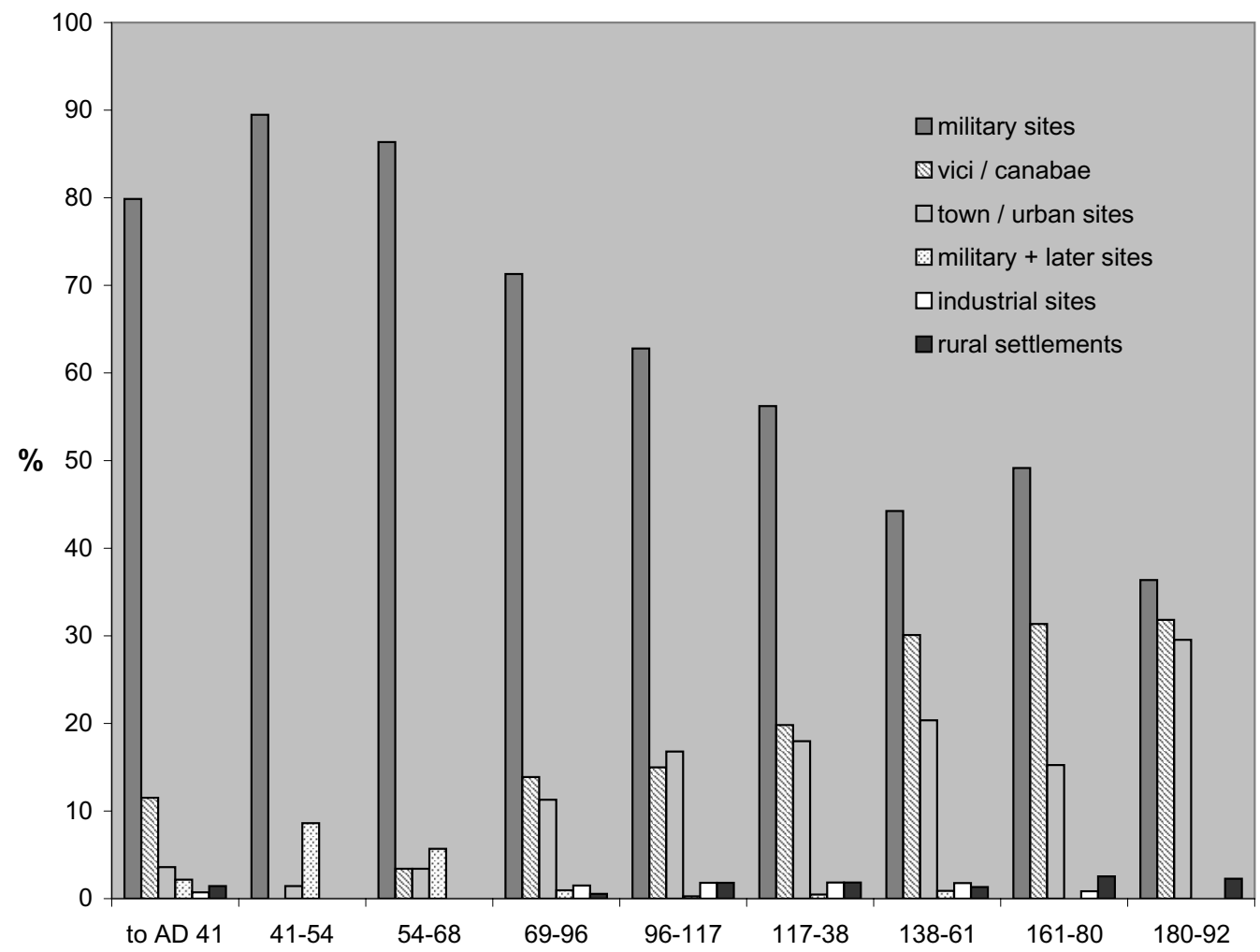

FIG. 10. Proportions of first- and second-century coins on sites in Wales.

cent for both categories) than vici/canabae, industrial sites, and rural settlements $(72,50$ and 67 per cent respectively, although the overall number of coins from industrial and rural sites is very small). After A.D. 69 the proportion of silver coins from Welsh sites falls to 14-22 per cent, while copper-alloy coins become slightly more common (FIG. 12). This picture is a consequence of patterns of coin production and supply to Wales, though it is interesting that non-military sites produce relatively more silver coins (particularly pre-A.D. 68 issues) than forts and towns. Also, it is noticeable that the categories of sites become very similar when coins after the conquest of Wales are considered. Presumably this indicates the existence of a Welsh regional circulation pool of Roman coins, at least in terms of ratios between high- and low-value coins, during the years of military occupation. Such a uniform pattern of coin circulation suggests that coins were frequently exchanged between sites, which explains why the developing urban and rural settlements of Wales never acquired their own distinctively non-military pattern of coin use, even after the withdrawal of the military garrison.

\section{A COIN ECONOMY?}

The impression of a uniform regional pool of circulating coins in Roman Wales fails to take into account the differences that existed at the local level. For example, south-west Wales produces a distinctive pattern of early Roman coin loss that appears to reveal a localised tradition of coin 


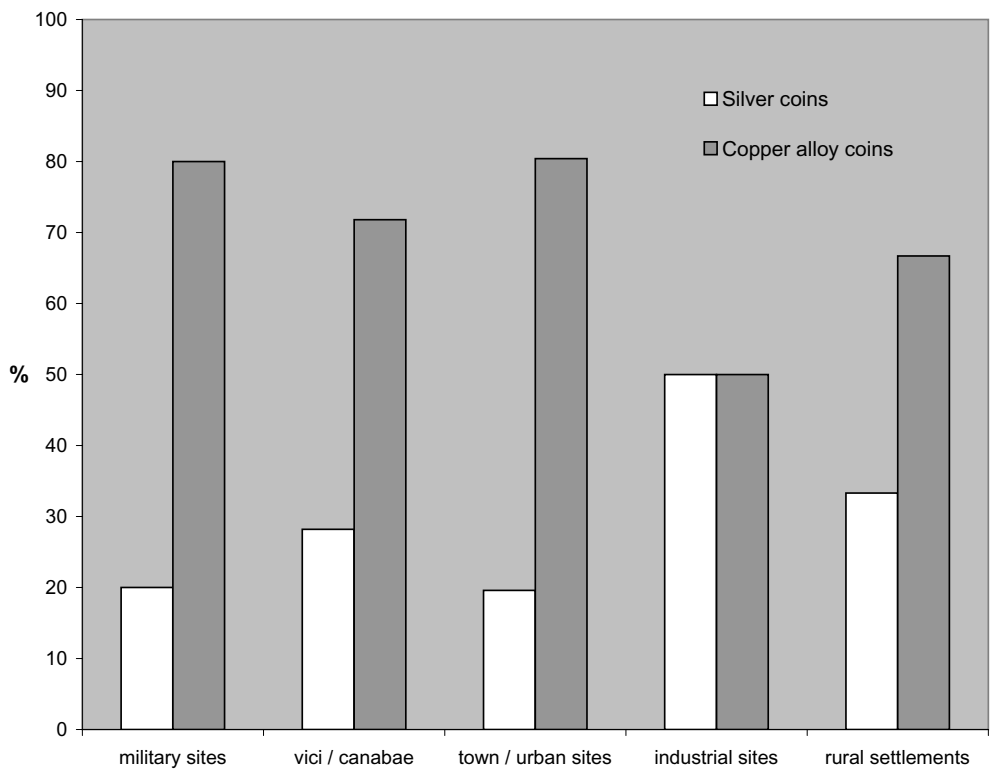

FIG. 11. Proportions of silver and bronze coins (Republic to A.D. 68) on sites in Wales.

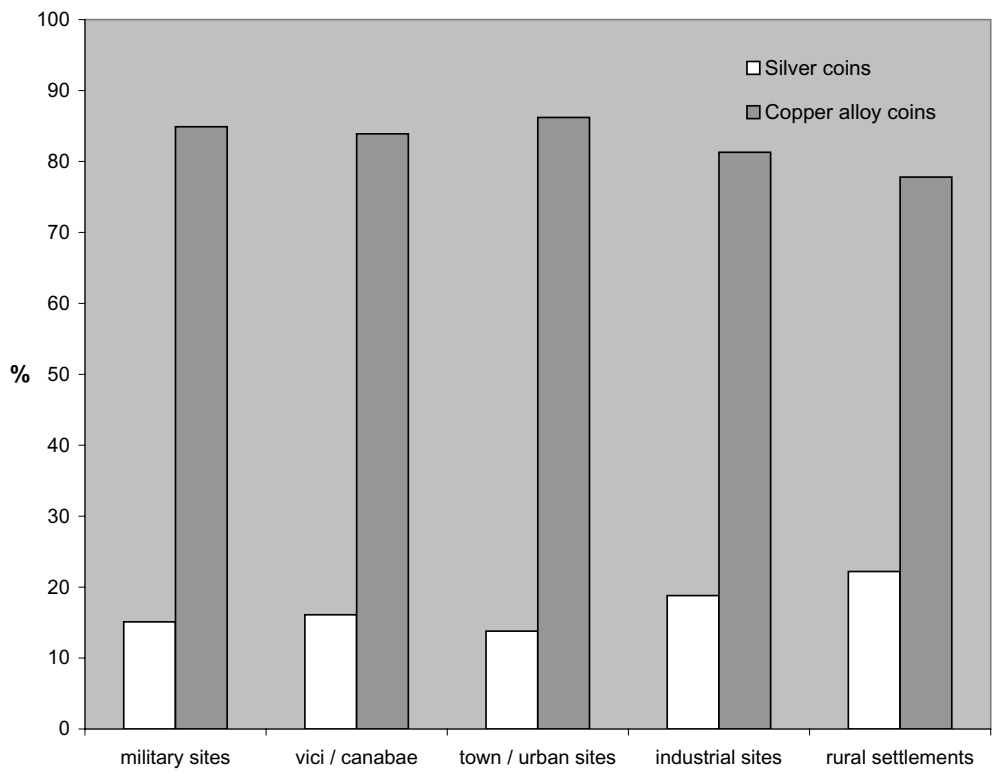

FIG. 12. Proportions of silver and bronze coins (A.D. 69 to 192) on sites in Wales. 


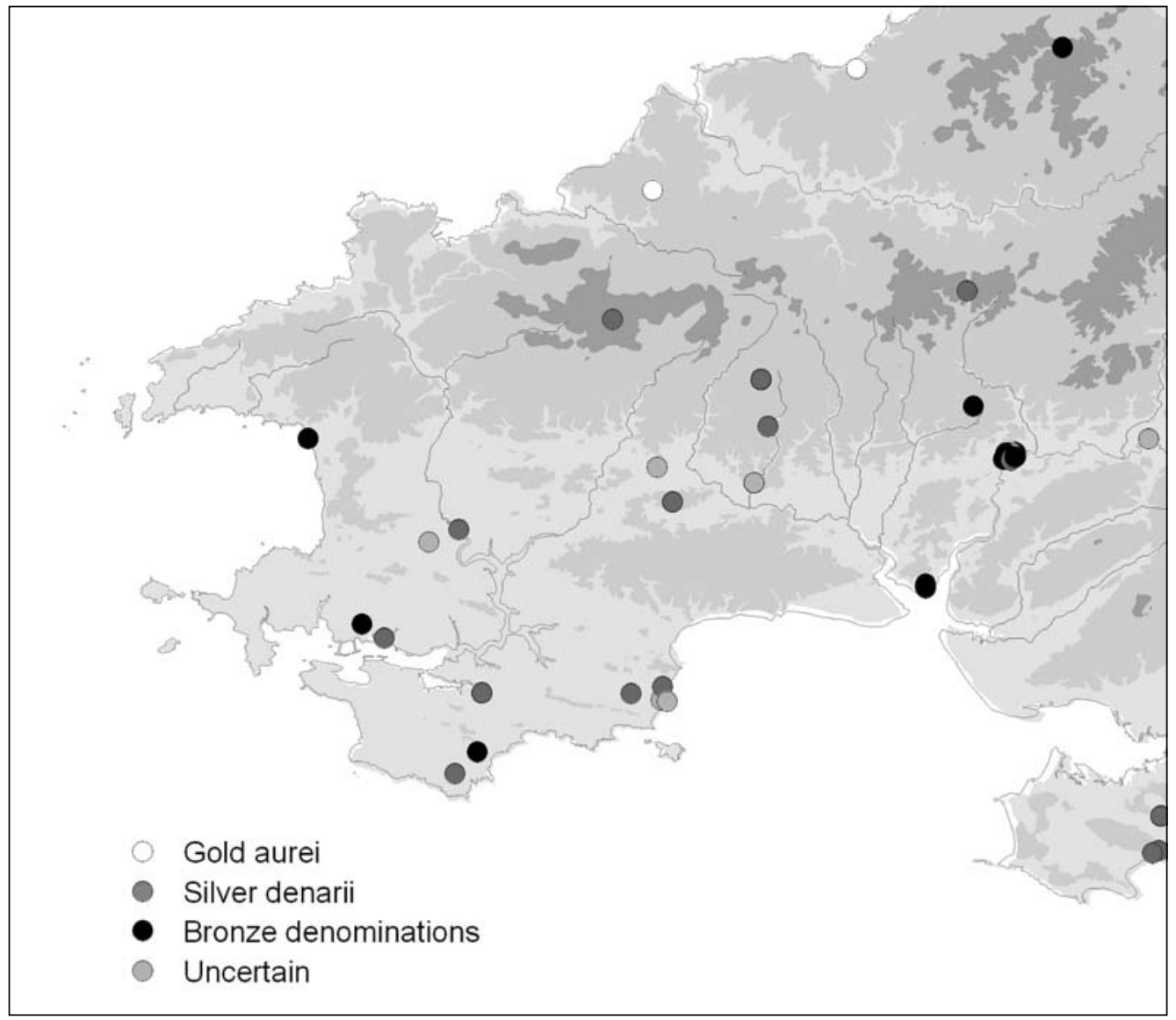

FIG. 13. Early Roman coins (Republic to A.D. 96) from south-west Wales by metal.

use (FIG. 13). Here, silver denarii and bronze coins of the first century and earlier (Republic to the reign of Domitian) are found on the coast and along rivers valleys such as the Towy, while only silver coins are known to have been recovered from within the hilly interior of the Pembrokeshire peninsula. These discrete distributions of silver and bronze coins suggest that high- and low-value coinage may have served different functions in south-west Wales during the earliest years of Roman occupation. When the circumstances of these coins' recovery is explored in more detail, it is apparent that silver coins from the interior tend to be found in hoards (or 'groups' that could have been hoards), while bronze coins are much more likely to originate as single finds and from 'groups' along the coast (FIG. 14). This highly suggestive pattern of coin loss could be explained if bronze coins were used mainly as a means of commercial exchange in locations where money was needed to enable such transactions to take place (primarily in locations along the coast and river estuaries). The predominance of silver denarii in the interior of Pembrokeshire, however, suggests that these intrinsically valuable coins were also used as a store of wealth, which could be hoarded away from parts where inter-regional exchanges took place (inland away from the coast and rivers). 


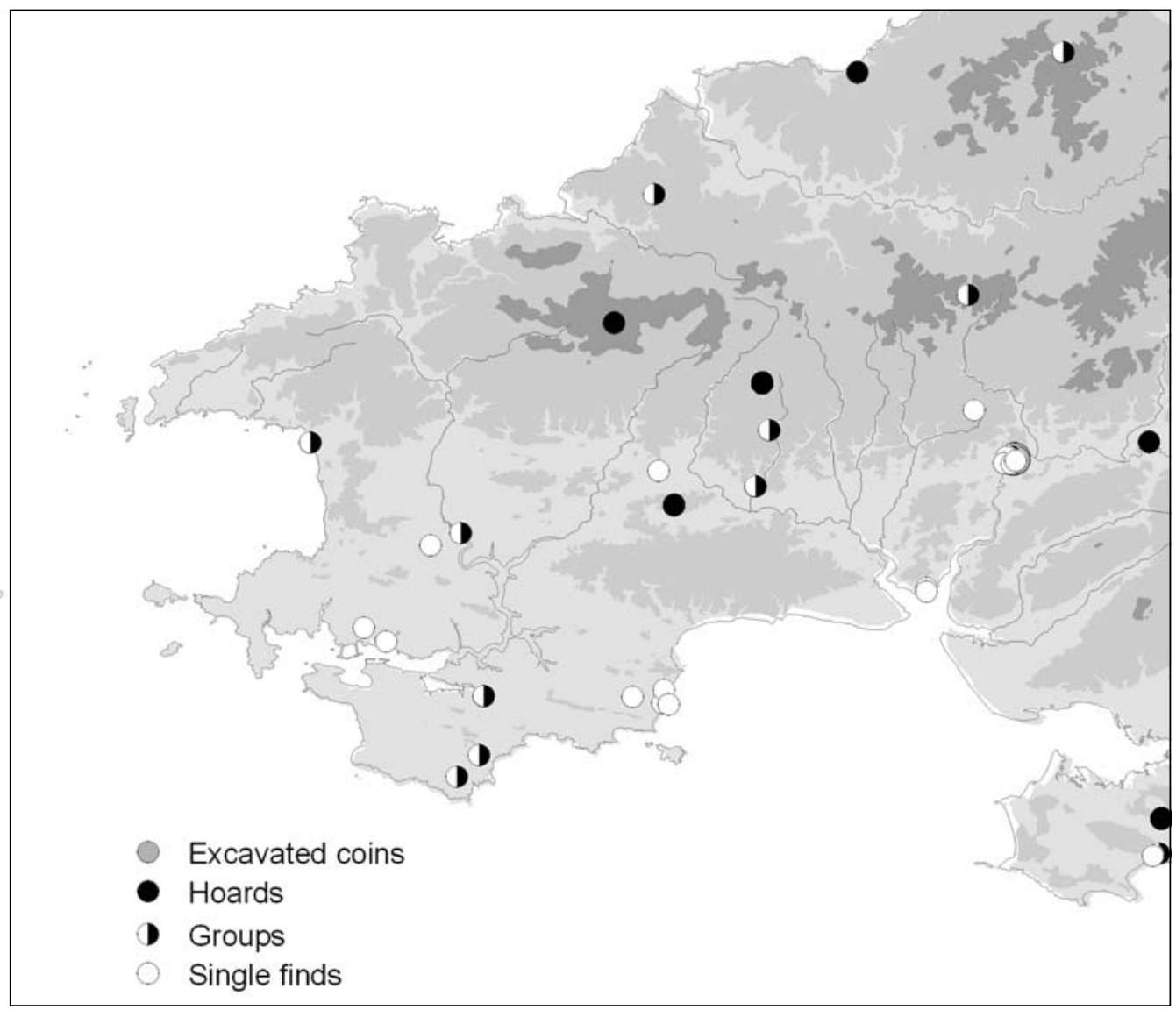

FIG. 14. Early Roman coins (Republic to A.D. 96) from south-west Wales by find type.

\section{DISCUSSION}

The systematic collection of numismatic data from an entire region of Britain means that it is possible to study the distribution of Late Iron Age and Roman coins from Wales in a relatively sophisticated way. Of course, this information could be used to explore broad historical questions, such as the production of Roman coinage at the imperial mints and the supply of coins to a province like Britannia, or the nature of the coin-using economy inside the Empire. Here, however, I would like to return to the questions posed at the beginning of this paper; questions that approach coins as part of the archaeology of Roman Wales.

TO WHAT EXTENT WERE COINS USED IN WALES BEFORE THE CONQUEST?

It is quite clear that Iron Age coins were lost only rarely in Wales, which presumably means that they were not used very often by the pre-Roman societies there. Bearing in mind that some of these coins were lost in the post-conquest period, the impression is that the population of Wales can hardly ever have seen a coin, except in the south-eastern corner of the country. Here coins 
of the neighbouring Dobunni are found in a line along the west bank of the River Wye, beyond which coinage apparently did not penetrate. It is significant that the coins recovered alongside the Wye are almost always single finds of gold coins from the hills above the river and it is unlikely that these were chance losses (silver issues are far more common from the territory of the Dobunni). Therefore, we have convincing evidence that coins of a certain metal were deliberately selected for deposition in specific places in Late Iron Age Wales - a custom that must have been a reaction to a culturally defined barrier that existed along the Wye and that must, to some extent, have defined the societies on either side. It is this definition of cultural difference that is archaeologically interesting and we might speculate whether such an efficient barrier to the spread of material culture was a political response to the Romanized coinage of the Dobunni, or a general cultural rejection of objects of particular metals, forms, or meanings. There may be other explanations, but it is also the case that the Silures (if that is what they called themselves) did not possess, or choose to bury, as rich a material culture as tribes further east and the patterns of loss described here look as if they are part of a more complex story. ${ }^{17}$

\section{HOW DID ROMAN COINS ARRIVE IN WALES?}

The monetization of Wales in the Roman period occurred suddenly and quickly. 4,565 early Roman coins (up to the death of Commodus in A.D. 192) are known from Wales compared to the 35 Iron Age coins, and it is clear that the population in large parts of the country would have used coins soon after the conquest. The earliest agents of monetization were the soldiers of the conquest and garrison units who were paid in coin and whose presence, it is assumed, would have stimulated a primitive moneyed economy in the hinterlands around the forts. It is certainly true that Claudian and Flavian coinage followed the army across Wales and also that coins are far less likely to be found in the hills and mountains of the interior than outside forts and their vici. However, this is not the entire picture and coins seem to have become a familiar part of material culture across most of lowland Wales within a generation or two of the conquest, suggesting either the very extensive influence of the army or other mechanisms for the widespread use of coinage. It is generally thought that the military would have paid in coin for all or some of the resources it requisitioned from the surrounding communities, yet there is also the distinct possibility that a moneyed 'economy' may have developed in Wales by other methods also, including the recruitment of soldiers and the settlement of retired veterans in the countryside. ${ }^{18}$

Roman coins could remain in circulation for many years after they were struck and care must be taken when interpreting their distributions - a good example being pre-Claudian coins, which were brought into Wales either by the army (and therefore many decades after they were issued), or before the conquest and contemporaneously with Iron Age coinage. However, it is apparent that the distribution of Republican coins, for example, is entirely different from the pattern of Iron Age issues (FIG. 15), indicating that the 253 Republican silver denarii from Wales were introduced during and after the Flavian conquest rather than before. In fact, the hoard evidence shows that, once in Britain, some Republican denarii were available to be lost well into the second century and we can conclude that their presence in Wales has nothing to do with prehistoric tribute, booty, or Caratacus. Most denarii struck during the Republic had disappeared from circulation by the beginning of the second century, although Mark Antony's 'legionary' denarii avoided being recycled until the end of the century when their lower, but still substantial, silver content was valuable enough to induce their recall to the mints. ${ }^{19}$ In Wales, 35 per cent of the Republican coins are 'legionary' denarii and the similarity of the distributions on FIGS 7 


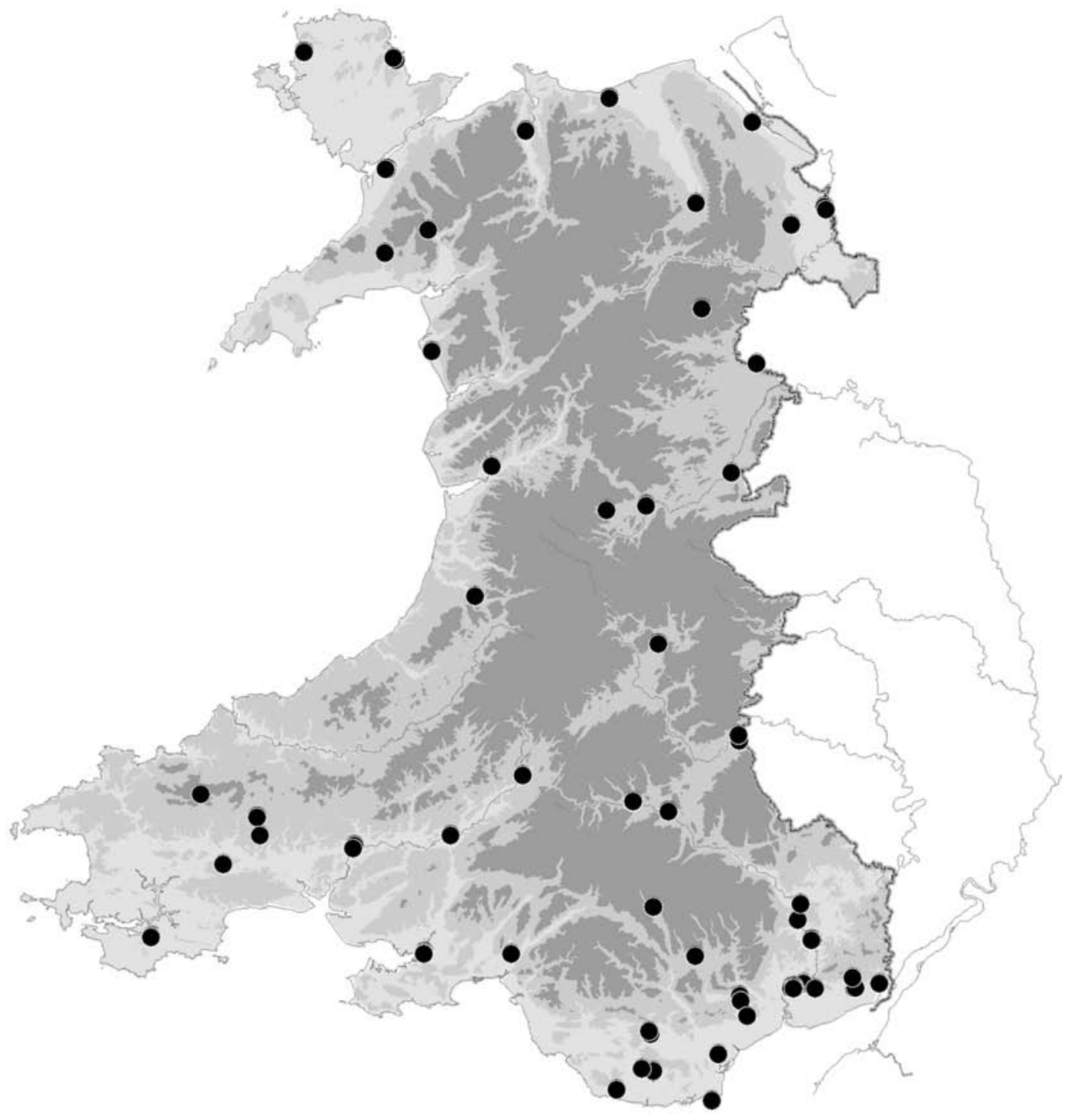

FIG. 15. Republican coins from Wales.

and 15 suggests that a significant proportion of Republican coinage was lost in the later first and early second centuries, or at least 120 years after they were struck.

WHAT FUNCTIONS DID ROMAN COINS PERFORM?

The evidence plainly shows that early Roman coinage in Wales was inextricably linked to the presence of the army for many years after the conquest. Nine out of every ten Claudian coins 
are found in forts and fortresses, while by the end of the second century military sites (together with their civilian suburbs) still account for almost two-thirds of coin finds from Wales. As well as being the standard means of payment to the army, Roman coins were also used as a means of exchange and the various denominations of the imperial coinage could have been used in all levels of commerce. However, the preponderance of coins from military sites throughout the early Roman period in Wales suggests that coin-using transactions at this time took place relatively rarely in the developing civilian world. Although the proportion of coins from towns, villas and other rural sites does increase during the second century, this rise is less dramatic than the decline in military coins over the same period, or, significantly, the increase in coins from vici and canabae attached to the forts and fortresses. It is also the case, however, that coin supply was maintained after the withdrawal of large numbers of troops to the north of Britain when coins appear to have been more widely available than ever before. Overall this pattern suggests that coins remained a predominantly military object in the early Roman period and that commercial exchange in specifically non-military contexts developed relatively slowly in Wales.

The third function with which Roman coins are often associated is the payment of taxes to the imperial treasury. In order to maintain the system of state spending on the army, upon which the security and stability of the Empire depended, vast quantities of silver bullion were needed to strike the coins with which the soldiers were paid. ${ }^{20}$ In a world of finite precious metal resources, providing sufficient silver to the mints on a regular basis meant recycling existing coinage, and taxation was the principal mechanism by which the Roman government attempted to achieve this delicate financial balancing act. ${ }^{21}$ In a landmark paper, Hopkins emphasized the role of coinage and taxation in the economy of ancient Rome. ${ }^{22}$ According to the Hopkins model, Roman Britain was a tax-importing province because the expenditure required to pay the military garrison would have far outweighed the revenues brought into the treasury through taxation. While others have since pointed out that not all taxes were paid in coin, it remains the case that taxation would have been a fact-of-life for most inhabitants of the Empire and that coinage was the obvious medium with which to pay and receive their taxes. ${ }^{23} \mathrm{We}$ might expect, therefore, that all parts of Britain should produce Roman coins as all free-born inhabitants had to pay taxes of one kind or another. In Wales, however, there are large areas that are devoid of coins (the central highlands and some coastal parts) and where Roman coinage cannot have been used to any great extent. ${ }^{24}$ The absence of coinage from much of the mountainous interior serves to emphasize the level of acculturation in most coastal areas, but also raises the question how people who did not use coins can have played their part in the global economy of the Roman Empire and paid tax? It is possible that some of these payments were made in kind, but we might also consider that the transhumant populations (who it is assumed inhabited the Welsh mountains) could have exchanged their produce for coins in specific places visited at particular times of the year. While this is highly speculative, more evidence should be sought for the use of forts, and any later civilian settlements, in the river valleys as locations for seasonal markets with their money-changers and imperial tax-collectors. ${ }^{25}$

20 Casey 1986, 14-15.

21 Crawford 1970

22 Hopkins 1980.

23 Duncan-Jones 1990.

24 It is increasingly unlikely that thousands of coins remain to be discovered in these areas.

25 A similar model has been put forward to explain the absence of Roman coins from other remote parts of SouthWestern Britain. High-status native settlements in Cornwall (known as 'rounds') might have acted as central locations where tax and commercial transactions took place - in other words, Roman officials would have come to appropriate places such as 'rounds' and collected the taxes of a dispersed community in a single visit (Quinnell 2004, 235). 


\section{CAN WE DETECT DIFFERENT RESPONSES TO ROMAN COINAGE, INCLUDING RESISTANCE?}

This is by far the most difficult question to answer and identifying the cause of an archaeological pattern is always a problematic exercise. For instance, the absence of Roman coins from the Lleyn Peninsula could be explained as a consequence of the indigenous society's environmental and economic conditions in this exposed part of Britain, or as a cultural response to Roman coinage and perhaps Roman-ness. Typically, it is not possible to determine which of these two explanations is closest to reality, because there is insufficient evidence from many parts of Wales with which to test different interpretations, though hopefully this will change with time.

A pattern of particular interest was observed in south-west Wales where distinctive spatial distributions of early Roman silver and bronze coins were identified. While both metals have been recovered along the coast and major river valleys, only silver coins are found in the interior of the Pembrokeshire peninsula, often together as hoards. This appears to indicate that Roman coins were used differently in these areas, perhaps in inter-regional transactions with external groups on the coast (trade or the payment of taxes and duties perhaps), while in the more isolated interior coins might have been seen as a store of wealth whose value was not necessarily measured in Roman terms. The prized nature of the silver denarius in south-west Wales is shown by the hoards of these coins found away from the main areas of settlement, often on hills or prominent places. These are characteristics of the deposition of other 'special' objects in Welsh archaeology and it would seem that in this region we have identified evidence for a primitive moneyed economy in which coins of various metals had different functions in specific locations. This is a complex picture of local responses to Roman coinage in south-west Wales, where the background of prehistoric traditions was at least as great an influence as new Roman practices and customs.

Wales was truly on the imperial fringe, and the coin evidence suggests that the day-to-day lives of the population in a substantial part of the country will have hardly changed for several generations after the arrival of the coin-using Romans.

\section{COPYRIGHT}

The background maps used to illustrate this article were derived from information compiled by RCAHMW (C) Crown copyright: Royal Commission on the Ancient and Historical Monuments of Wales) and from Ordnance Survey material with the permission of Ordnance Survey on behalf of the Controller of her Majesty's Stationery Office (C) Crown copyright. Unauthorised reproduction infringes Crown copyright and may lead to prosecution or civil proceedings (National Museums and Galleries of Wales Contractor Licence 100017916). The numismatic data were compiled by the Iron Age \& Roman Coins from Wales project, (c) Cardiff University.

Cardiff University

guestp@cardiff.ac.uk

\section{BIBLIOGRAPHY}

Aarts, J. 2003: 'Monetization and army recruitment in the Dutch river area in the first century AD', in T. Grünewald and S. Seibel (eds), Kontinuität und Diskontinuität, Germania Inferior am Beginn und am Ende der römische Herrschaft, Berlin, 162-80

Arnold, C.J., and Davies, J.L. 2000: Roman and Early Medieval Wales, Stroud

Boon, G.C. 1964: 'The coins', in W. Gardner and H.N. Savory, Dinorben: A Hillfort Occupied in Early Iron Age and Roman Times, Cardiff, 114-30

Boon, G.C. 1965: 'Coins', in L.M. Threipland, 'Caerleon: Museum Street Site, 1965', Archaeologia Cambrensis 114, 140-1 
Boon, G.C. 1967: 'The Penard Roman imperial hoard: an interim report and a list of Roman hoards in Wales', Bulletin of the Board of Celtic Studies 22.3, 291-310

Boon, G.C. 1975: 'A list of Roman hoards in Wales - first supplement 1973', Bulletin of the Board of Celtic Studies 26.2, 237-40

Boon, G.C. 1978: 'A list of Roman hoards in Wales - second supplement 1977', Bulletin of the Board of Celtic Studies 27.4, 625-32

Boon, G.C. 1982: 'The coins', in W. Manning, Report on the Excavations at Usk 1965-1976, Cardiff, 3-42

Boon, G.C. 1988: 'Appendix: British coins from Wales', in D.M. Robinson (ed.), Biglis, Caldicot and Llandough. Three Late Iron Age and Romano-British Sites in South-East Wales. Excavations 1977-79, BAR British Series 188, Oxford, 92

Casey, P.J. 1986: Understanding Ancient Coins, London

Casey, P.J. 1988: 'The interpretation of Romano-British site finds', in P.J. Casey and R. Reece (eds), Coins and the Archaeologist (2nd edn), London, 39-56

Casey, P.J. 1989: 'Coin evidence and the end of Roman Wales', Archaeological Journal 146, 320-9

Crawford, M.H. 1970: 'Money and exchange in the Roman world', Journal of Roman Studies 60, 40-8

Davies, J.L. 1983: 'Coinage and settlement in Roman Wales and the Marches: some observations', Archaeologia Cambrensis 132, 78-94

Davies, J.L. 1984: 'Soldiers, peasants and markets in Wales and the Marches', in T.F.C. Blagg and A.C. King (eds), Military and Civilian in Roman Britain, BAR British Series 136, Oxford, 93-127

Duncan-Jones, R. 1990: Structure and Scale in the Roman Economy, Cambridge

Fasham, P.J., Kelly, R.S., Mason, M.A., and White, R.B. 1998: The Graeanog Ridge. The Evolution of a Farming Landscape and its Settlements in North-West Wales, Aberystwyth

Guest, P., and Wells, N. 2007: Iron Age \& Roman Coins from Wales, Collection Moneta 66, Wetteren

Gwilt, A. 2007: 'Silent Silures: locating people and places in the Iron Age of south Wales', in C. Haselgrove and T. Moore (eds), The Later Iron Age in Britain and Beyond, Oxford, 297-328

Haselgrove, C. 1993: 'The development of British Iron-Age coinage', Numismatic Chronicle 155, 31-63

Hobley, A. 1998: An Examination of Roman Bronze Coin Distribution in the Western Empire, A.D. 81-192, BAR British Series 688, Oxford

Hopkins, K. 1980: 'Taxes and trade in the Roman empire (200 B.C.-A.D. 400)', Journal of Roman Studies $70,101-25$

Jarrett, M.G. 2002: 'Early Roman campaigns in Wales', in R.J. Brewer (ed.), The Second Augustan Legion and the Roman Military Machine, Cardiff, 45-66

Jones, G.D.B. 1990: 'Searching for Caradog', in B. Burnham and J. Davies (eds), Conquest, Co-existence and Change: Recent Work in Roman Wales, Trivium 25, Lampeter, 57-64

Kelly, R.S. 1990: 'Recent research on the hut group settlements of north-west Wales', in B. Burnham and J. Davies (eds), Conquest, Co-existence and Change: Recent Work in Roman Wales, Trivium 25, Lampeter, $102-11$

Kent, J.P.C. 1988: 'Interpreting coin finds', in P.J. Casey and R. Reece (eds), Coins and the Archaeologist (2nd edn), London, 201-17

Kenyon, R. 1987: 'The Claudian coinage', in N. Crummy (ed.), The Coins from Excavations in Colchester 1971-9, Colchester Archaeological Report 4, Colchester, 24-41

Lockyear, K. 2007: 'Where do we go from here? Recording and analysing Roman coins from archaeological contexts', Britannia 37, 211-24

Longley, D., Johnstone, N., and Evans, J. 1998: 'Excavations on two farms of the Romano-British period at Bryn Eryr and Bush Farm, Gwynedd', Britannia 29, 85-246

MacDonald, P., and Davies, M. 2002: 'Old Castle Down revisited: some recent finds from the Vale of Glamorgan', in M. Aldhouse-Green and P. Webster (eds), Artefacts and Archaeology: Aspects of the Celtic and Roman World, Cardiff, 20-32

Manning, W.H. 2002: 'Early Roman campaigns in the south-west of Britain', in R.J. Brewer (ed.), The Second Augustan Legion and the Roman Military Machine, Cardiff, 27-44

Manning, W.H. 2003: 'The conquest of Wales', in M. Todd (ed.), A Companion to Roman Britain, Oxford, 60-74

Moore, T. 2007: 'Life on the edge: exchange, community, and identity in the later Iron Age of the SevernCotswolds', in C. Haselgrove and T. Moore (eds), The Later Iron Age in Britain and Beyond, Oxford, $41-61$ 
Nash-Williams, V.E. 1928: 'Topographical list of Roman remains found in South Wales', Bulletin of the Board of Celtic Studies 4.3, 246-71

Quinnell, H. 2004: Trethurgy. Excavations at Trethurgy Round, St Austell: Community and Status in Roman and Post-Roman Cornwall, Cornwall

Reece, R. 1987: Coinage in Roman Britain, London

Reece, R. 1996: 'The interpretation of site finds - a review', in C. King and D.G. Wigg (eds), Coin Finds and Coin Use in the Roman World, Studien zu Fundmünzen der Antike 10, Berlin, 341-55

Reece, R. 2002: The Coinage of Roman Britain, Stroud

Walker, D. 1988: 'Roman coins from the Sacred Spring at Bath', in B. Cunliffe (ed.), The Temple of Sulis Minerva at Bath, II: Finds from the Sacred Spring, OUCA Monograph 16, Oxford, 281-338

Wheeler, R.E.M. 1923a: 'Roman coin-hoards in Wales', Bulletin of the Board of Celtic Studies 1.4, 345-52, 370

Wheeler, R.E.M. 1923b: 'Roman coin-hoards; addenda', Bulletin of the Board of Celtic Studies 2.1, 91-2 